\title{
Herbs to support cancer care: Challenges and opportunities
}

\author{
Murthy KNC* and Alice Hepsiba S \\ Principal Scientist, Central Research Laboratory, MS Ramaiah Medical College \& Hospitals, India
}

Submission: February 01, 2017; Published: August 16, 2018

*Corresponding author: Murthy KNC, Principal Scientist, Central Research Laboratory, MS Ramaiah Medical College\& Hospitals, MSR Nagar, MSRIT Post, Bangalore-560 054, India, Tel: +91-80-40502772; Email: kncmurthy@gmail.com

\begin{abstract}
Application of plant and plant derived compounds in management and treatment of cancer dates back to early 19th century. More than $60 \%$ of the drugs clinically used for treatment or management of cancer today are either modifications or derivatives of natural products. Natural molecules have shown success due to their safety to normal or noncancerous cells along with ability to trigger multiple pathways for targeting cancer cells. These natural molecules were used in modified form to either achieve optimum pharmacokinetic parameters or for optimum activity. Conversely, many of the herbs (whole herbs, parts of herbs, crude or semi processed extracts) have been explored benefit in both treatment and management of tumors of different origin and molecular character. Most of these studies are well documented using in vitro, cell lines or animal models and very few reports are available reading clinical studies. The available clinical studies are either observational or retrospective analysis of very few cases. In this article, we are discussing the advantages of herbaceuticals (Herbs and its preparations) for cancer care and challenges in subjecting these products for clinical studies. Information will also be provided regarding existing opportunity and challenges to undertake scientific clinical investigations of herbs for supporting cancer care.
\end{abstract}

Keywords: Cancer care; Clinical studies; Herbaceuticals; Integrated medicine; Traditional medicine

Abbreviations: VRLB: Vinorelbine; VDS: Vindesine: WHO: World Health Organization; EFCAM: European Federation for Complementary and Alternate Medicine

\section{History of Plant Based Treatment of Cancer}

Natural products from plants serve as most promising source of potential drug leads [1]. Estimation of the world's diversity for potential biological aspect is less than 10 , a myriad of applicable natural lead compounds await discovery [2]. In addition to most popular Indian system of medicine Ayurveda (herbs were major medicines uses), which is 5000 year old (Approx. $3000 \mathrm{BC}$ ), there are several reports from other parts of the world. The ancient records of natural products from Mesopotamia (2600 B.C.) were delineated on clay tablets in cuneiform which documented oils from Cupressus sempervirens (Cypress) and Commiphora species (Myrrh) which are being used till date to treat coughs, colds and inflammation. An Egyptian pharmaceutical record, The Ebers Papyrus (2900 B.C.) has documented over 700 plant-based drugs ranging from gargles, pills, infusions, to ointments. Arabs were the first people to own private pharmacies (8th century) with Avicenna, a Persian pharmacist, physician, philosopher and poet, volunteering much to pharmacy and medicine through works such as the Canon Medicinae [3]. This speaks about application of herbs as medicine globally from ancient period. Application of natural products as medicines has been portrayed throughout history in the form of traditional medicines, remedies, potions and oils. The utility and knowledge of natural product from medicinal plants results from the experimentation by man for hundreds of centuries through palatability trials or the occurrence of untimely deaths, quest for available herbs for the treatment of diseases [4].

Plants have evolved and adapted over millions of years to withstand pathogens, insects, fungi and climate and seasons to produce unique, structurally diverse secondary metabolites [5]. These molecules have shown ability to treat several pathological conditions in human, which includes cancer and inflammation. According to World Health Organization (WHO), about $80 \%$ of people still rely on plant-based components as traditional medicines for primary health care [6]. The health benefits rendered from traditional medicine from plants has promoted further studies and investigations of medicinal plants as potential therapeutic medicines and has also paved way to the isolation of many natural products which are been well established pharmaceuticals used globally.

\section{Application of Plant Based Molecules/ Derivatives in Treatment of Cancer}

Paclitaxel (Taxol ${ }^{\circledR}$ ), isolated from the bark of Taxus brevifolia (Pacific Yew) is a commonly used well known drug for breast 
cancer [3]. Ingenol 3-0-angelate a derivative of the polyhydroxy diterpenoid ingenol isolated from the sap of Euphorbia peplus, is a potential chemotherapeutic agent for skin cancer and is clinical development by Peplin Biotech for the topical treatment of certain skin cancers [7-8]. Combretastatin A-4 phosphate, a stilbene derivative from the South African Bush Willow, Combretum caffrum acts as an anti-angiogenic agent causing vascular shutdowns in tumors (necrosis) and has compleated Phase II clinical trials [9].

As mentioned earlier, plants play a major role as effective anti- cancer agents, and it is reported that about $60 \%$ of anticancer agents used currently are derived from natural sources, including plants, marine organisms and micro-organisms $[3,10]$. Vinca alkaloids, vinblastine and vincristine, and the isolation of the cytotoxic podophyllotoxins were the earliest notable discoveries of anti-cancer agents, dated to 1950's. It is said that any of the new plant based anticancer agents are yet to reach the general use, as a number of them ate in preclinical development [11].

Vinblastine and vincristine isolated from the Madagascar periwinkle, Catharanthus roseus G. Don. (Apocynaceae), were the first few plant derived agents to enter clinical use and they were used for primarily treating diabetes [12]. The study of these agents as potential oral hypoglycemic agents, it was observed that these extracts reduced the count of white blood cells and caused the depression of bone marrow in mice, and subsequently they were found to be active against lymphocytic leukemia in mice. This paved a way for the isolation of these compounds. Recently these compounds are prepared in semisynthetic analogs called vinorelbine (VRLB) and vindesine (VDS). These agents are used in combination with other cancer chemotherapeutic drugs for the treatment of a range of cancers, including leukemias, lymphomas, advanced testicular cancer, breast and lung cancers, and Kaposi's sarcoma. Etoposide (VM 26) and teniposide (VP 16-213 are two clinically active compounds which are semi-synthetic derivatives of epipodophyllotoxin (an isomer of podophyllotoxin), which are used for the treatment of cancer [13]. The Podophyllum species of Indian subcontinent regions have been used since ancient days for the treatment of skin cancer and warts. The species includes Podophyllum peltatum Linnaeus (commonly known as the American mandrake or Mayapple), and Podophyllum emodii Wallich. Etoposide and teniposide are two other efficient agents that were discovered for the treatment of lymphomas and bronchial and testicular cancers. The exploration of taxanes was a major stepping stone towards the treatment of cancer [14]. Paclitaxel (taxol@) was isolated initially from the bark the Pacific Yew, Taxus brevifolia Nutt. (Taxaceae). The use of various parts of Taxus brevifolia and other Taxus species (e.g., Taxus Canadensis Marshall, Taxus baccata L.) by Native American tribes for the treatment of some cancer and non-cancerous conditions has been reported, [15]. Baccatins, one of the several key precursors of paclitaxel occurs in the leaves of various Taxus species. Its native and semi-synthetic form of baccatins along with docetaxel
(Taxotere ${ }^{\circledR}$ ), paclitaxel analogs, stands as a major class of anticancer drugs. Paclitaxel remains as one of the potential agents in the treatment of breast, ovarian, and non-small cell lung cancer, while docetaxel is primarily used in the treatment of breast cancer and non-small cell lung cancer.

Another important addition to the anti-cancer drug armamentarium is the class of clinically active agents derived from. Camptothecin (as its sodium salt) was advanced to clinical trials by the NCI in the 1970s, but was dropped later because of severe bladder toxicity, but extensive research led to the development of more effective derivatives, Topotecan and Irinotecan (CPT-11; Camptosar). Topotecan, a derivative of camptothecin, isolated from the Chinese ornamental tree, Camptotheca acuminata Decne (Nyssaceae) [16] is used for the treatment of ovarian and small cell lung cancers. Another derivative of camptothecin, Irinotecan is used for the treatment of colorectal cancers.

\section{Application of plant phytochemicals in cancer}

A whole range of chemical compounds have been developed for the treatment of cancer. They impose limitations due to their inability to solely targeting the cancer cells [17]. Naturally derived compounds from plants stands as an absolute alternative source to overcome these issues.

The secondary metabolites synthesized in plants such as polyphenols, flavonoids and brassinosteroids have been extensively extracted and studied for their potential use as anticancer agents. They possess a range of anticancer activities which include; antioxidant activity; inhibition of cancer cell growth; induction of apoptosis; target specificity; cancer cell cytotoxicity $[18,19]$. These natural compounds are available readily from the natural environment and are relatively nontoxic to human cells. Nanotechnology has been a development in administration of anticancer compounds and therapies in the form of nanoparticles. The method allows the controlled and sustained release of the active agents and reduces the severe side effects. Treatment and prevention of cancer using plant based compounds is attributed to their safety, low cost, and oral bioavailability. Cancer conventional therapies like chemotherapy and radiotherapy can induce side effects such as myelosuppression and neurological, cardiac, pulmonary, and renal toxicity, which pose serious harm to the quality of life [20]. This necessitates the need of more potent and less toxic anticancer drugs.

\section{Limitations of plants in cancer care}

The demand for plant-derived drugs is increasing the pressure on potential medicinal plants and risking their biodiversity [21]. In spite of huge demand for natural and alternate sources of chemotherapeutic and chemo preventive molecules or formulation, we are not able to identify most efficient formulation due several limitation. This includes, Lack of scientific evidence on benefit of herbs and herbaceuticals 
in cancer care, which includes toxicity profile, molecular mechanism, information about active principles. Unlike synthetic drug molecules, there are no guidelines for clinical investigations of plant based or dietary ingredients. As working principles of traditional medicine and modern medicine are different, it is difficult to follow the evaluation model for clinical investigations [22-27]. There are several efforts to address this issues globally through National Institute of Health (USA), Department of AYUSH (India), Complementary and integrative medicine (Australia), European federation for complementary and alternate medicine (EFCAM), Complementary and Natural Healthcare council (UK), traditional Chinese medicine (China), traditional medicine (Republic of Korea), traditional system (Africa). These bodies are focusing on application of alternative (where herb based is the major components) medicine for selected health conditions for which there is no definite remedy in modern medicine. As a part of such health condition, cancer is most common disease addressed by complementary/ alternate system of medicine for both treatment and management. In many countries, there are no guidelines, licensing authority for use and practice of alternate or traditional system of medicine [28-35]. However, the same can be used by qualified health care practitioners who have good knowledge of its safety and efficacy.

In order to overcome these limitations, it may be a good idea to have an international forum or guidelines on the use of plant based or natural medicines for health care and promotion. Such a forum should encourage researchers and medicine practitioners across the discipline to join hands to fight against cancer. They should encourage and support joint efforts of researchers from Agriculture, Modern medicine, Chemistry, Botany, Pharmacology, Alternate system of medicine, Pharmaceutical sciences and Molecular biology to address the complexity of issue in integrated manner. Additionally, specific guidelines for undertaking research on clinical utility of herbs and natural products should be included to existing polity or a separate guidance to be made $[36,37]$. Chemical, Taxonomical profiling should be done to each of the herb used and optimized protocol to be established for cultivation, collection and processing of each plant material used. This can specifically help to address the issue related to variation in active ingredients in different plants (caused due to seasonal and time of harvest or collection of plant material), which is a major concern in herbaceuticals [38-44].

\section{Summary}

It is well established fact that most of the successful clinical chemotherapeutic drugs have history natural origin specifically from herbs. With lot of challenges posed by signs and symptoms of cancer due to genetic and molecular complexity, we are not successful in addressing the same effectively for last 5 decades. The only ray of hope during this period was findings on several herbs and its constituents, which have shown positive repose towards inhibiting tumor and associated pathological conditions. We have discussed these results in our previous article (Swaroop et al., 2014). These findings are either in preclinical and clinical studies with very small size. There are several evidences of clinical success from alternate and traditional medicine practitioners which is either not documented or poorly documented. Scientific clinical investigations with integrated approach among traditional, integrated and modern medicine practitioners may provide best solutions. Along with this some of the legal and statutory bodies governing different system of medicine should come up with regulations that can support such integrative approach for better outcome. Asia and Africa are known for rich and diverse source of herbs with medicinal value, integration of researchers from this continent with other advanced scientist of natural products, combinatorial chemistry and advanced molecular medicine may provide better outcome towards search of best medicine for cancer care (Table 1 \& 2) [22-44].

Table 1: Herbs known for prevention of cancer incidences based on in vitro, in vivo studies (Adopted from Raina et al., 2014).

\begin{tabular}{|c|c|c|c|}
\hline Herb/ Plant name & Active Phytochemicals & Major activity/ mode of action & References \\
\hline Actaea racemosa $L$. & Cycloartenol, Actein & $\begin{array}{l}\text { Inhibits proliferation of human breast cancer cells and } \\
\text { human liver cancer cells (HepG2) }\end{array}$ & 22 \\
\hline Allium sativum $L$. & $\begin{array}{l}\text { Allylmercaptocysteine and } \\
\text { thioallyl compounds }\end{array}$ & $\begin{array}{l}\text { Antiproliferative effect of thioallyl against breast and } \\
\text { prostate cell lines Inhibition of IL-6 }\end{array}$ & 23 \\
\hline $\begin{array}{l}\text { Andrographis paniculata Wall. ex } \\
\text { Nees }\end{array}$ & $\begin{array}{l}\text { Deoxyandrographolide, } \\
\text { andrographolide }\end{array}$ & $\begin{array}{l}\text { expression, suppresses IL-6-mediated signals, and } \\
\text { induces cell apoptosis by the activation of apoptosis- } \\
\text { related proteins/ MAPKs, cytotoxic agent in the case } \\
\text { of liver cancer }\end{array}$ & 24 \\
\hline Ardisia crenata Roxb & $\begin{array}{c}\text { Alkenylphenol, Ardisiacrispins A } \\
\text { and B }\end{array}$ & $\begin{array}{l}\text { Inhibits the uncontrolled proliferation by inducing } \\
\text { proapoptotic and microtubule disruptive activities. }\end{array}$ & 25 \\
\hline Boswellia serrata Roxb. & $\begin{array}{l}\text { Acetyl-11-keto- } \beta \text {-boswellic acid } \\
\text { (AKBA) }\end{array}$ & $\begin{array}{l}\text { Inhibition of multiple steps of VEGF-induced cell } \\
\text { proliferation, migration, invasion, and tube formation. }\end{array}$ & 26 \\
\hline Catharanthus roseus (L.) G.Don & Vinblastine and Vincristine & $\begin{array}{c}\text { Curative effects against human neoplasms. Therapy } \\
\text { for lymphosarcoma, choriocarcinoma, neuroblastoma, } \\
\text { and carcinoma of the breasts, lungs and other organs } \\
\text { in acute and chronic leukemia.. }\end{array}$ & 27 \\
\hline
\end{tabular}




\begin{tabular}{|c|c|c|c|}
\hline Centella asiatica $L$. & $\begin{array}{l}\text { Glycoside asiaticoside, Asiatic, } \\
\text { madecassic acid. }\end{array}$ & $\begin{array}{l}\text { Decrease the viability of HepG } 2 \text { cells due to increased } \\
\text { expression of a tumor-suppressor p53 gene mediated } \\
\text { by increased levels of intracellular calcium }\end{array}$ & 28 \\
\hline Curcuma longa $L$. & Curcumin & $\begin{array}{l}\text { Antitumor potential via suppression of transcription } \\
\text { factor, NF- } \mathrm{B} \text {, AP-1, and STAT- } 3 \text {. Also repress pro- } \\
\text { inflammatory pathways of COX-2 and iNOS }\end{array}$ & 29 \\
\hline Fagara zanthoxyloides $L$. & $\begin{array}{l}\text { Benzophenanthridine alkaloid } \\
\text { fagaronine }\end{array}$ & $\begin{array}{l}\text { Antitumor activity against murine leukemic cell lines } \\
\text { in vivo. Fagaronine inhibits the DNA replication of } \\
\text { rapidly growing cancer cells by inhibiting DNA and } \\
\text { RNA polymerase activities and protein synthesis }\end{array}$ & 30 \\
\hline Glycyrrhiza glabra $L$. & $\begin{array}{c}\text { Isoliquiritigenin } \\
\left(2^{\prime}, 4^{\prime}, 4 \text {-trihydroxychalcone }\right)\end{array}$ & $\begin{array}{l}\text { Induction of phase II enzymes such as quinone } \\
\text { reductase } 1 \text {, increased expression of glutathione } \\
\text { peroxidase 5, and downregulation of several } \\
\text { cytochrome P450 genes }\end{array}$ & 31 \\
\hline Glycyrrhiza glabra L. & $\begin{array}{l}\text { Terpenoids, alkaloids, and } \\
\text { glycosides Indirubin }\end{array}$ & $\begin{array}{l}\text { Potent inhibitor of cyclin-dependent kinases. Inhibits } \\
\text { the proliferation Cells by arresting the cells in the } \\
\text { G2/M phase of the cell cycle }\end{array}$ & 32 \\
\hline Mangifera indica $L$. & Triterpene called lupeol & $\begin{array}{c}\text { Induce apoptosis in human epidermoid carcinoma } \\
\text { A431 cells. Induction of apoptosis in association } \\
\text { with the caspase-dependent mitochondrial cell } \\
\text { death pathway. It also inhibits the Akt/PKB } \\
\text { signaling pathway by inhibition of Bad (Ser136) } \\
\text { phosphorylation. }\end{array}$ & 33 \\
\hline Morinda citrifolia $L$. & $\begin{array}{l}\text { Glycosides, 6-O- }(\beta \text {-D- } \\
\text { glucopyranosyl)-1-Ooctanoyl- } \\
\beta \text {-D-glucopyranose and } \\
\text { asperulosidic acid, }\end{array}$ & $\begin{array}{l}\text { Inhibiting TPA- or EGF-promoted cell transformation } \\
\text { as well as related AP-1 activity in the mouse epidermal } \\
\text { JB6 cell line (Liu et al., 2001). Increased }\end{array}$ & 34 \\
\hline Nigella sativa $L$. & Thymoquinone, & $\begin{array}{c}\text { Supression of NF-kB, Akt activation, and extracellular } \\
\text { signal-regulated kinase signaling pathways; it also } \\
\text { inhibits tumor angiogenesis }\end{array}$ & 29 \\
\hline Panax ginseng C.A.Mey. & Saponins, Ginsenosides & $\begin{array}{c}\text { Antiproliferation, antiinvasion, and antiangiogenesis } \\
\text { properties. }\end{array}$ & 35 \\
\hline Plumbago zeylanica $L$. & Plumbagin, quinoid & $\begin{array}{l}\text { Inhibitory against molecular targets like protein } \\
\text { kinase C epsilon (a PCa proliferative marker), STAT-3, } \\
\text { AKT, and PI-3K result in the inhibition of growth and } \\
\text { invasion of PCa. }\end{array}$ & 36 \\
\hline 36Rhinacanthus nasutus (L.) Kurz & $\begin{array}{l}\text { Rhinacanthins } \mathrm{M}, \mathrm{N} \text {, and } \mathrm{Q} \text { and } \\
\text { related }\end{array}$ & $\begin{array}{l}\text { The partial arrest of cells at the } \mathrm{G} 2 / \mathrm{M} \text { has been } \\
\text { observed and leads to apoptosis }\end{array}$ & 37 \\
\hline Scutellaria baicalensis Georgi & Baicalein, Wogonin, Wogonoside & Inhibition of 12-lipoxygenase activity & 38 \\
\hline Solanum incanum $L$. & Solamargine & $\begin{array}{l}\text { Potential as an anticancer agent for tumor necrosis } \\
\text { factors and Bcl-2-related resistance of human lung } \\
\text { cancer cells }\end{array}$ & 39 \\
\hline Vismia laurentii De Wild. & Xanthone V1 & $\begin{array}{l}\text { Apoptosis induction, and caspase- } 3 / 7 \text { activity in } \\
\text { the CCRF-CEM cell line and show evidence for its } \\
\text { anticancer potential as a cytotoxic agent. }\end{array}$ & 40 \\
\hline
\end{tabular}

Table 2: Native and traditional herbs undergone clinical studies and used in traditional practice of medicine.

\begin{tabular}{|c|c|c|c|c|}
\hline Plant/ herb & Part or formulation & Cancer and study design & Major findings & References \\
\hline Turmeric & $\begin{array}{l}\text { Powder of rhizomes of } \\
\text { Curcuma Sp., }\end{array}$ & Colon cancer Phase-I & $\begin{array}{l}3.6 \mathrm{~g} \text { showed significant decreases in } \\
\text { PGE2 }\end{array}$ & 41 \\
\hline Morinda citrifolia (Noni) & Fruit Juice & & Immune boosting & 42 \\
\hline Astragalus species & $\begin{array}{l}\text { Whole herb along with } \\
\text { other drugs }\end{array}$ & $\begin{array}{l}\text { Non-small lung cancer Meta- } \\
\text { Analysis of Randomized Trials }\end{array}$ & $\begin{array}{l}\text { Astragalus-based Chinese herbal } \\
\text { medicine may increase effectiveness of } \\
\text { platinum-based chemotherapy when } \\
\text { combined with chemotherapy. }\end{array}$ & 43 \\
\hline $\begin{array}{l}\text { Kampo Medicines- } \\
\text { Traditional Japanese } \\
\text { medicines }\end{array}$ & Consist of $5-12$ herbs & $\begin{array}{l}\text { Hepatic cancer Phase III } \\
\text { randomized trial }\end{array}$ & Up to $40 \%$ reduction in death & 44 \\
\hline $\begin{array}{l}\beta \text {-Gluean Mushroom } \\
\text { Extracts }\end{array}$ & Polysaeeharide K (PSK) & Colorectal Randomized trail & $\begin{array}{l}\text { Increased disease free status and } \\
\text { survival }\end{array}$ & 44 \\
\hline
\end{tabular}


Journal of Complementary Medicine \& Alternative Healthcare

\begin{tabular}{|c|c|c|c|c|}
\hline Green tea & Tea & $\begin{array}{c}\text { Case control study Colon and } \\
\text { rectal cancer }\end{array}$ & Reduced the overall burden \\
\hline Mistletoe & $\begin{array}{c}\text { Refers to Viscum album } \\
\text { species }\end{array}$ & $\begin{array}{c}\text { Randomized trail Head and } \\
\text { neck cancer }\end{array}$ & Better outcome \\
\hline Essiac & $\begin{array}{c}\text { Consist of Burdoek, } \\
\text { Turkey rhubarb, Sorrel, } \\
\text { Slippery elm }\end{array}$ & $\begin{array}{c}\text { Observational studies Colon } \\
\text { and other cancers }\end{array}$ & Overall survival and quality of life \\
\hline
\end{tabular}

\section{Acknowledgement}

Authors would like to thank the management of MS Ramaiah Medical College \& Hospital for their support and encouragement for research.

\section{References}

1. Mishra BB, Tiwari VK (2011) Natural products: An evolving role in future drug discovery. Eur J Med Chem 46(10): 4769-4807.

2. Cragg GM, Newman DJ (2005) Plants as a source of anti-cancer agents. Journal of ethnopharmacology 100(1-2): 72-79.

3. Cragg GM (1998) Paclitaxel (Taxol): A success story with valuable lessons for natural product drug discovery and development. Med Res Rev 18: 315-331.

4. Kinghorn AD, Pan L, Fletcher JN, Chai H (2011) The relevance of higher plants in lead compound discovery programs. J Nat Prod 74(6): 1539-1555.

5. McRae J, Yang Q, Crawford R, Palombo W (2007) Review of the methods used for isolating pharmaceutical lead compounds from traditional medicinal plants. Environmentalist 27(1): 165-174.

6. Farnsworth NR, Akerele RO, Bingel AS, Soejarto DD, Guo Z (1985) Medicinal Plants in Therapy. Bull. WHO 63(6): 965-981.

7. Kedei N, Lundberg DJ, Toth A, Welburn P, Garfield SH, et al. (2004) Characterization of the interaction of ingenol 3-angelate with protein kinase C. Cancer Res 64(9): 3243-3255.

8. Ogbourne SM, Suhrbier A, Jones B (2004) Antitumour activity of ingenol 3-angelate: Plasma membrane and mitochondrial disruption and necrotic cell death. Cancer Res 64(8): 2833-2839.

9. Newman DJ, Cragg GM (2005) In: Drug Discovery, Therapeutics, and Preventive Medicine. Zhang L, Fleming A, Demain AL (eds.), Humana Press; Totowa, NJ, USA, pp. 74-91.

10. Newman DJ, Cragg GM, Snader KM (2003) Natural products as sources of new drugs over the period 1981-2002. Journal of Natural Products. 66: 1022-1037.

11. Swaroop MN, Chidambara Murthy KN, Chandrashekhar MS, Rao RM (2014) Natural molecules as tumour inhibitors: Promises and prospects. Journal of Herbal Medicine 4(4):175-187.

12. Gueritte F, Fahy J (2005) The vinca alkaloids. In: Cragg GM, Kingston DGI, Newman DJ (Eds.), Anticancer Agents from Natural Products. Brunner-Routledge Psychology Press, Taylor \& Francis Group, Boca Raton, FL, pp. 123-136.

13. Lee KH, Xiao Z (2005) Podophyllotoxins and analogs. In: Cragg GM, Kingston DGI, Newman DJ (Eds.), Anticancer Agents from Natural Products. Brunner-Routledge Psychology Press, Taylor \& Francis Group, Boca Raton, FL, pp. 71-88.

14. Kingston DGI (2005) Taxol and its analogs. In: Cragg GM, Kingston DGI Newman DJ (Eds.), Anticancer Agents from Natural Products. BrunnerRoutledge Psychology Press, Taylor \& Francis Group, Boca Raton, FL, pp. 89-122 (Chapter 6).

15. Hartwell JL (1982) Plants Used Against Cancer. Quarterman, Lawrence, MA.
16. Rahier, NJ, Thomas CJ, Hecht SM (2005) Camptothecin and its analogs. In: Cragg GM, Kingston DGI, Newman DJ (Eds.), Anticancer Agents from Natural Products. Brunner-Routledge Psychology Press, Taylor \& Francis Group, Boca Raton, FL, pp. 5-22.

17. Ochwang'I DO, Kimwele CN, Oduma JA, Gathumbi PK, Mbaria JM (2014) Medicinal plants used in treatment and management of cancer in Kakamega County Kenya. Journal of Ethnopharmacology. 151(3): 1040-1055.

18. Gupta SC, Tyagi AK, Deshmukh-Taskar P, Hinojosa M, Prasad S, et al. (2014) Downregulation of tumor necrosis factor and other proinflammatory biomarkers by polyphenols. Archives of Biochemistry and Biophysics 559: 91-99.

19. Cao J, Xia X, Chen X, Xiao J, Wang Q (2013) Characterization of flavonoids from Dryopteris erythrosora and evaluation of their antioxidant, anticancer and acetylcholinesterase inhibition activities. Food and Chemical Toxicology 51: 242-250.

20. Alonso-Castro AJ, Villarreal ML, Salazar-Olivo LA, Gómez-Sánchez M, García-Carranco A (2011) Mexican medicinal plants used for cancer treatment: Pharmacological, phytochemical and ethnobotanical studies. Journal of Ethnopharmacology 133(3): 945-972.

21. Kumar S, Pathania AS, Saxena AK, Vishwakarma RA, Ali A, et al. (2013) The anticancer potential of flavonoids isolated from the stem bark of Erythrina suberosa through induction of apoptosis and inhibition of STAT signalling pathway in human leukaemia HL-60 cells. ChemicoBiological Interactions 205(2): 128-137.

22. Einbonda LS, Soffritti M, Esposti DD, Park T, Cruz E, et al. (2009) Actein activates stressand statin-associated responses and is bioavailable in Sprague- Dawley rats. Fund Clin Pharmacol 23(3): 311-321.

23. Sigounas G, Hooker J, Anagnostou A, Steiner M (1997) S-Allylmercaptocysteine inhibits cell proliferation and reducesthe viability of erythroleukemia, breast, and prostate cancer cell lines. Nutr Cancer 27(2): 186-191.

24. Ji L, Liu T, Liu J, Chen Y, Wang Z (2007) Andrographolide inhibits human hepatoma-derived Hep3B cell growth through the activation of c-Jun N-terminal kinase. Planta Med 73(13): 1397-1401.

25. Li M, Wei SY, Xu B, Guo W, Liu DL, et al. (2008) Proapoptotic and microtubule-disassembly effects of ardisiacrispin $(A+B)$, triterpenoid saponins from Ardisia crenata on human hepatoma Bel-7402 cells. J Asian Nat Prod Res 10(7-8): 729-736.

26. Pang X, Yi Z, Zhang X, Sung B, Qu W, et al. (2009) Acetyl-11-keto-bboswellic acid inhibits prostate tumor growth by suppressing vascular endothelial growth factor receptor 2-mediated angiogenesis. Cancer Res 69(14): 5893-5900.

27. Noble RL (1990) The discovery of the vinca alkaloids-chemotherapeutic agents against cancer. Biochem Cell Biol 68(12): 1344-1351.

28. Lee YS, Jin DQ, Kwon EJ, Park SH, Lee ES, (2002) Asiatic acid, a triterpene, induces apoptosis through intracellular $\mathrm{Ca} 2+$ release and enhanced expression of p53 in HepG2 human hepatoma cells. Cancer letters 186 (1)): 83-91.

29. Plengsuriyakarn T, Viyanant V, Eursitthichai V, Picha $P$, Kupradinun $P$, et al. (2012) Anticancer activities against cholangiocarcinoma, toxicity and pharmacological activities of Thai medicinal plants in animal models. BMC Complement Altern Med 12: 23-32. 
30. Fleury F, Sukhanova A, Ianoul A, Devy J, Kudelina I, et al. (2000) Molecular determinants of site-specific inhibition of human DNA topoisomerase I by fagaronine and ethoxidine. Relation to DNA binding J Biol Chem 275: 3501-3509.

31. Cuendet M, Guo J, Luo Y, Chen S, Oteham CP, et al. (2010) Cancer chemopreventive activity and metabolism of isoliquiritigenin, a compound found in licorice. Cancer Prev Res (Phila) 3(2): 221-232.

32. Hoessel R, Leclerc S, Endicott JA, Nobel ME, Lawrie A, et al. (1999) Indirubin, the active constituent of a Chinese antileukaemia medicine, inhibits cyclin dependent kinases. Nature Cell Biol 1(1): 60-67.

33. Prasad S, Madan E, Nigam N, Roy P, George J, et al. (2009) Induction of apoptosis by lupeol in human epidermoid carcinoma A431 cells through regulation of mitochondrial,Akt/PKB and $\mathrm{NFkB}$ signaling pathways. Cancer Biol Ther 8(17): 1632-1639.

34. Liu G, Bode A, Ma WY, Sang S, Ho CT, (2001) Two novel glycosides from the fruits of Morinda citrifolia (noni) inhibit AP-1 transactivation and cell transformation in the mouse epidermal JB6 cell line. Cancer Res 61(15): 5749-5756.

35. Yue PY, Mak NK, Cheng YK, Leung KW, Ng TB, et al. (2007) Pharmacogenomics and the Yin/Yang actions of ginseng: antitumor angiomodulating and steroidlike activities of ginsenosides. Chinese Med 2: 6-11.

36. Aziz MH, Dreckschmidt NE, Verma AK (2008) Plumbagin, a medicinal plant-derived naphthoquinone, is a novel inhibitor of the growth and invasion of hormone-refractory prostate cancer. Cancer Res 68(21): 9024-9032.

This work is licensed under Creative

Commons Attribution 4.0 License

DOI: 10.19080/JCMAH.2018.06.555696
37. Siripong P, Yahuafai J, Shimizu K, Ichikawa K, Yonezawa S, et al. (2006) Antitumor activity of liposomal naphthoquinone esters isolated from Thai medicinal plant: Rhinacanthus nasutus Kurz. Biol Pharma Bull 29(11): 2279-2283.

38. Zhou Y, Gao W, Li K (2008) Chinese herbal medicine in the treatment of lung cancer. Asian J Tradit Med 3: 1-11.

39. Liu LF, Liang CH, Shiu LH, Lin WL, Lin CH, et al. (2004) Action of solamargine on human lung cancer cells--enhancement of the susceptibility of cancer cells to TNFs. FEBS Lett 577(1-2): 67-74.

40. Kuete V, Eyong KO, Folefoc GN, Beng VP, Hussain H, et al. (2007) Antimicrobial activity of the methanolic extract and of the chemical constituents isolated from Newbouldia laevis. Pharmazie 62: 552-556.

41. Sharma RA, Euden SA, Platton SL, Cooke DN, Shafayat A, et al. (2004) Phase I clinical trial of oral curcumin. Clinical Cancer Research 10(20): 6847-54.

42. Wong DK (2004) Are immune responses pivotal to cancer patient's long term survival? Two clinical case-study reports on the effects of Morinda citrifolia (Noni). Hawai Medical Journal 63: 182-184.

43. McCulloch M, See C, Shu XJ, Broffman M, Kramer A, et al. (2006) Astragalus-based Chinese herbs and platinum-based chemotherapy for advanced non-small-cell lung cancer: meta-analysis of randomized trials. Journal of Clinical Oncology 24(3): 419-430.

44. Vickers A (2002) Botanical medicines for the treatment of cancer: rationale, overview of current data, and methodological considerations for phase I and II trials. Cancer investigation 20(7-8): 1069-1079.

\section{Your next submission with Juniper Publishers will reach you the below assets}

- Quality Editorial service

- Swift Peer Review

- Reprints availability

- E-prints Service

- Manuscript Podcast for convenient understanding

- Global attainment for your research

- Manuscript accessibility in different formats

(Pdf, E-pub, Full Text, Audio)

- Unceasing customer service

Track the below URL for one-step submission https://juniperpublishers.com/online-submission.php 